\title{
ADAM Family Gene
}

National Cancer Institute

\section{Source}

National Cancer Institute. ADAM Family Gene. NCI Thesaurus. Code C20791.

ADAMs (A Disintegrin and Metalloproteinase Domain) are membrane-anchored

proteases that regulate cell behavior by proteolytically modifying the cell surface and extracellular matrix. Currently, the ADAM family has 29 members, although the function of most ADAM gene products is unknown. The ADAM gene products with known functions act in a highly diverse set of biological processes, including fertilization, neurogenesis, myogenesis, embryonic T GF-alpha release and the inflammatory response. (from J Cell Biol 2002;159:893-902 and NCl) 